\title{
FINANCIAMENTO DA SEGURANÇA PÚBLICA PRECISA DE ATENÇÃO
}

Coluna publicada em 6.5.2014: <http://www.conjur.com.br/2014-mai-06/ contas-vista-financiamento-seguranca-publica-atencao $>$

Assunto que sempre está na ordem do dia, a questão da violência e, por consequência, da segurança pública, tem sido objeto de maior destaque nas últimas semanas, em que se tem observado um - no mínimo aparente - aumento da criminalidade. Crimes que têm chocado a população, greves de policiais, situação prisional degradante em alguns estados e sucateamento de órgãos de investigação: o noticiário foi farto nos últimos dias em más notícias na área da segurança pública e nos obriga a pensar mais sobre o assunto.

Trata-se de tema que envolve inúmeros aspectos e áreas do conhecimento humano e, portanto, de grande complexidade não só na sua compreensão, mas também e principalmente na busca das melhores soluções para resolver as inúmeras e relevantes questóes que ele suscita.

E como usualmente acontece, pouco se aborda o aspecto que é, regra geral, o mais importante: o financeiro.

A segurança pública é "dever do Estado, direito e responsabilidade de todos", nas claras palavras do artigo 144 da Constituição. Uma das mais importantes atribuições de todo e qualquer Estado Democrático de Direito, pois não há como se alcançá-lo e mantê-lo sem que se garanta a preservação da ordem pública e incolumidade das pessoas e do patrimônio, funções que nossa Constituição lhe atribui. Função essencialmente de Estado e bem público com características de indivisibilidade e não especificidade, a segurança pública deve ser garantida diretamente pelo poder público e pouco se pode contar com a colaboração do setor privado e terceiro setor.

Essas razóes colaboram para torná-la um serviço caro - muito caro. Os direitos têm custos, como bem ressaltaram Stephen Holmes e Cass Sustein em sua 
clássica obra (The cost of rights, 2000), e a segurança pública é um de seus exemplos mais evidentes.

A segurança pública, se analisada de forma abrangente, constitui-se em um sistema bastante complexo, pois, além de incluir os órgãos que a compõem mencionados no artigo 144 da Constituição da República (polícias federais, civis, militares e corpo de bombeiros), também envolve o Poder Judiciário, Ministério Público, Força Nacional, Guardas Municipais, assim como todo o sistema de administração penitenciária. ${ }^{1}$ Poderes, órgãos e instituições, que, como se pode ver, pertencem aos vários entes da federação. Um direito que não se consegue implementar por uma ou poucas ações governamentais, mas por um conjunto de várias políticas públicas que devem se coordenar e complementar para atingir seu objetivo.

Um sistema que, como se pode ver, precisa alcançar resultados mediante a coordenação de entes federados e poderes independentes em todo o país. E, mesmo dentro de um mesmo Poder de um ente da federação, exige a ação conjunta de órgãos sob comandos diferentes. Veja-se, no âmbito do Poder Executivo Federal, as várias polícias (comum, rodoviária, ferroviária); e nos Poderes Executivos dos Estados, as polícias civil e militar.

Vê-se haver uma multiplicidade de comandos, órgãos e orçamentos, cuja cooperação é fundamental para atingir o objetivo maior de atender a necessidade pública de mais segurança e menos violência.

Não é de se surpreender que o financiamento deste serviço público fundamental seja caro, complexo e difícil de ser planejado e gerenciado, o que só reforça a necessidade de que sejam priorizados esses aspectos.

Tendo em vista que todos os entes da federação participam na segurança pública, seus custos se espalham pelos inúmeros orçamentos públicos, órgãos e respectivos programas governamentais, tornando difícil, se não impossível, saber precisamente quanto do dinheiro público lhe é destinado. Mas algumas informações permitem constatar a elevada dimensão desses gastos.

Expressivas quantidades de recursos são vinculadas à segurança pública por meio de vários fundos orçamentários. No âmbito federal, destacam-se o Fundo Nacional de Segurança Pública (FNSP) e o Fundo Penitenciário Nacional (Funpen), ${ }^{2}$ cujos montantes, para este ano de 2014, são da ordem de 500 milhões de reais cada

E nem incluo as Forças Armadas, que ao se responsabilizar pela defesa nacional, poderiam ser consideradas em uma interpretação lato sensu da segurança pública.

2 Este último recentemente completou 20 anos de existência, tendo sido criado pela Lei Complementar 79, de 1994. 
um, gerenciados pelo Ministério da Justiça. Isso representa apenas uma parcela muito pequena do que se gasta, pois esses recursos são basicamente destinados à capacitação e qualificação de servidores, modernização e reequipamento dos órgãos de segurança pública e administração penitenciária dos demais entes da federação e financiamento de programas voltados à redução da violência, não incluindo, portanto, aquela que é a despesa mais representativa - o pagamento de pessoal.

Há ainda programas específicos no orçamento federal voltados à segurança pública, como o Programa Nacional de Segurança Pública (Pronasci), ${ }^{3}$ importante fonte de transferências voluntárias destinadas a financiar projetos para os entes subnacionais, em regime de cooperação federativa.

A função segurança pública, no orçamento federal para 2014, prevê gastos na ordem de $\mathrm{R}$ \$ 8,5 bilhôes, e é importante ressaltar que a maior parte dos serviços relacionados à segurança pública está nos orçamentos dos estados, que administram as polícias civis e militares estaduais.

No Estado de São Paulo, que tem o maior orçamento entre os estados-membros de nossa federação, para se ter uma ideia, só na Secretaria da Segurança Pública, principal responsável pelos programas nesta área, na qual estão as polícias civil e militar, tem orçamento de quase $\mathrm{R} \$ 18$ bilhōes para este exercício de 2014 . Se somados aos R \$ 4 bilhões destinados à Secretaria da Administração Penitenciária, perfazem um montante de R \$ 22 bilhões. Mas não é só. Programas também importantes para a proteção da sociedade e redução da violência estão em outros órgãos, como a Secretaria da Justiça, que administra o Programa Estadual de Direitos Humanos, o de Perícia Judicial, o de Modernização da Fundação Casa e o de Atenção ao Adolescente e de Integração das Medidas Socioeducativas de Internação e Semiliberdade, o que permite acrescentar mais R \$ 1,5 bilhão a essa conta. $\mathrm{Ou}$ seja, o estado de São Paulo destina anualmente em torno de $\mathrm{R} \$ 25$ bilhões para tentar assegurar à população uma sociedade com ordem pública e sem violência. É praticamente equivalente aos gastos de toda a cidade do Rio de Janeiro, a segunda maior do país, cujo orçamento municipal para este ano de 2014 é da ordem de R \$ 27 bilhões. E mesmo assim, não consegue atingir os objetivos esperados nem remunerar adequadamente seus policiais.

Considerando-se que a segurança pública no Estado de São Paulo conta com a participação do governo federal, não só na transferência de recursos, mas também na atuação direta, por meio dos órgãos federais, como a polícia federal, sem esquecer das ações a cargo dos municípios do estado, muitos dos quais dispõem de guardas

3 Previsto na Lei 11.530, de 2007, alterada pela Lei 11.707, de 2008. 
municipais e outros órgãos e serviços que atuam para colaborar na redução da violência, chega-se à conclusão de que os valores mencionados estão longe de representar os reais gastos públicos nessa área, que são muito maiores.

Algo precisa ser feito, pois, apesar dessa quantidade fantástica de dinheiro público, o que se vê, muitas vezes, em todo o país são delegacias mal equipadas, presídios em situação lastimável e policiais sem equipamentos adequados para exercer a função. Policiais que, na maior parte dos órgãos e entes da federação, são mal remunerados, o que se é de lamentar, pois, mais do que em outras profissões, colocam sua vida em risco ao cumprir suas funções.

E, dadas as variedade e quantidade de órgãos e entes da federação envolvidos, não há como se generalizar haver má gestão de recursos certamente presentes em boa parte dos órgãos, como ocorre em toda a administração pública, mas sem dúvida com exceções.

Muito há que se fazer. Tramita no Congresso Nacional projeto de lei regulamentando o artigo $144, \$ 7^{\circ}$, da Constituição, voltado a organizar a segurança pública e garantir a eficiência de suas atividades, por meio da criação do Sistema Único de Segurança Pública (Susp) e, apesar de todos os fatos e acontecimentos recentes, pouco se debate o assunto.

Há que se dar maior atenção e avançar nas discussões sobre o financiamento da segurança pública, a fim de buscar soluções que fujam da solução simplista de maior aporte de recursos que, nesse caso, é ainda mais difícil de viabilizar dado o expressivo volume de dinheiro envolvido. Debater a prioridade nas políticas públicas de prevenção, afinal melhor é não haver violência, mas sem descuidar da repressão, pois sem ela a impunidade impera e corrompe todo o sistema. Conveniência, oportunidade, legalidade, interesse, extensão de participação da iniciativa privada e do terceiro setor, especialmente na área da proteção à criança e ao adolescente e administração penitenciária; forma de financiar a construção e manutenção de presídios, com a utilização de instrumentos como parcerias público-privadas ou outros meios de contratação; realização de audiências por videoconferência para evitar os custos de deslocamento de detentos; penas alternativas, diminuindo os custos do encarceramento -, enfim, há muitas despesas cuja possibilidade de redução precisa ser avaliada, a fim de verificar se são adequadas e viáveis para dar mais qualidade ao gasto público na área da segurança pública.

Se bem gerenciados, os recursos destinados à segurança pública estão entre os mais bem aplicados, pois os custos da violência são imensuráveis. Mortes de inocentes, sensação de insegurança, impunidade, falta de liberdade e tranquilidade são prejuízos que não têm preço. 